\title{
Long-term plasticity determines the postsynaptic response to correlated afferents with multivesicular short-term synaptic depression
}

\author{
Alex D Bird ${ }^{1,2,3^{*}}$, Magnus JE Richardson ${ }^{1}$ \\ From The Twenty Third Annual Computational Neuroscience Meeting: CNS*2014 \\ Québec City, Canada. 26-31 July 2014
}

The firing rate of a neuron is largely determined by correlations in synaptic drive. Correlations in neurotransmitter release between different active sites arise from both synchronous activity in the presynaptic population and the number of independent release sites per neuron. Recent work has shown that the number of release sites on each neuron is modified during long-term plasticity [1]. Such changes will modulate the effect of synchronous drive and therefore have a significant effect on the response of the postsynaptic cell.

To understand how correlations from synaptic dynamics and from presynaptic synchrony shape the postsynaptic response, we studied a model of multiple release site short-term plasticity and derived exact results for the crosscorrelation function of vesicle occupancy and neurotransmitter release, as well as the postsynaptic voltage variance [2]. Using approximate forms for the postsynaptic firing rate in the limits of low and high correlations, we demonstrated that short-term depression leads to a maximum response for an intermediate number of presynaptic release sites, and that this leads to a tuning-curve response peaked at an optimal presynaptic synchrony set by the number of independent neurotransmitter release sites per presynaptic neuron (Figure 1).

These effects arise because, above a certain level of correlation, activity in the presynaptic population is overly strong resulting in wastage of the pool of releasable neurotransmitter. As the nervous system operates under metabolic constraints it is likely that this

\footnotetext{
* Correspondence: a.d.bird@warwick.ac.uk

${ }^{1}$ Warwick Systems Biology Centre, University of Warwick, Coventry CV4 7AL, UK
}

Full list of author information is available at the end of the article phenomenon provides an activity-dependent constraint on network architecture.

\begin{abstract}
Authors' details
${ }^{1}$ Warwick Systems Biology Centre, University of Warwick, Coventry CV4 7AL, UK. ${ }^{2}$ Warwick Systems Biology DTC, University of Warwick, Coventry CV4 7AL, UK. ${ }^{3}$ School of Life Sciences, University of Warwick, Coventry CV4 7AL, UK.
\end{abstract}

Published: 21 July 2014

\section{References}

1. Loebel A, Le Be JV, Richardson MJE, Markram H, Herz AVM: "Matched Preand Post-Synaptic Changes Underlie Synaptic Plasticity over Long Time Scales,". J Neurosci 2013, 33:6257-6266.

2. Bird AD, Richardson MJE: "Long-term plasticity determines the postsynaptic response to correlated afferents with multivesicular shortterm synaptic depression,". Front Comput Neurosci 2014, 8, Article 2.

doi:10.1186/1471-2202-15-S1-P61

Cite this article as: Bird and Richardson: Long-term plasticity determines the postsynaptic response to correlated afferents with multivesicular short-term synaptic depression. BMC Neuroscience 2014 15(Suppl 1):P61.

Submit your next manuscript to BioMed Central and take full advantage of:

- Convenient online submission

- Thorough peer review

- No space constraints or color figure charges

- Immediate publication on acceptance

- Inclusion in PubMed, CAS, Scopus and Google Scholar

- Research which is freely available for redistribution

Submit your manuscript at www.biomedcentral.com/submit
() Biomed Central 


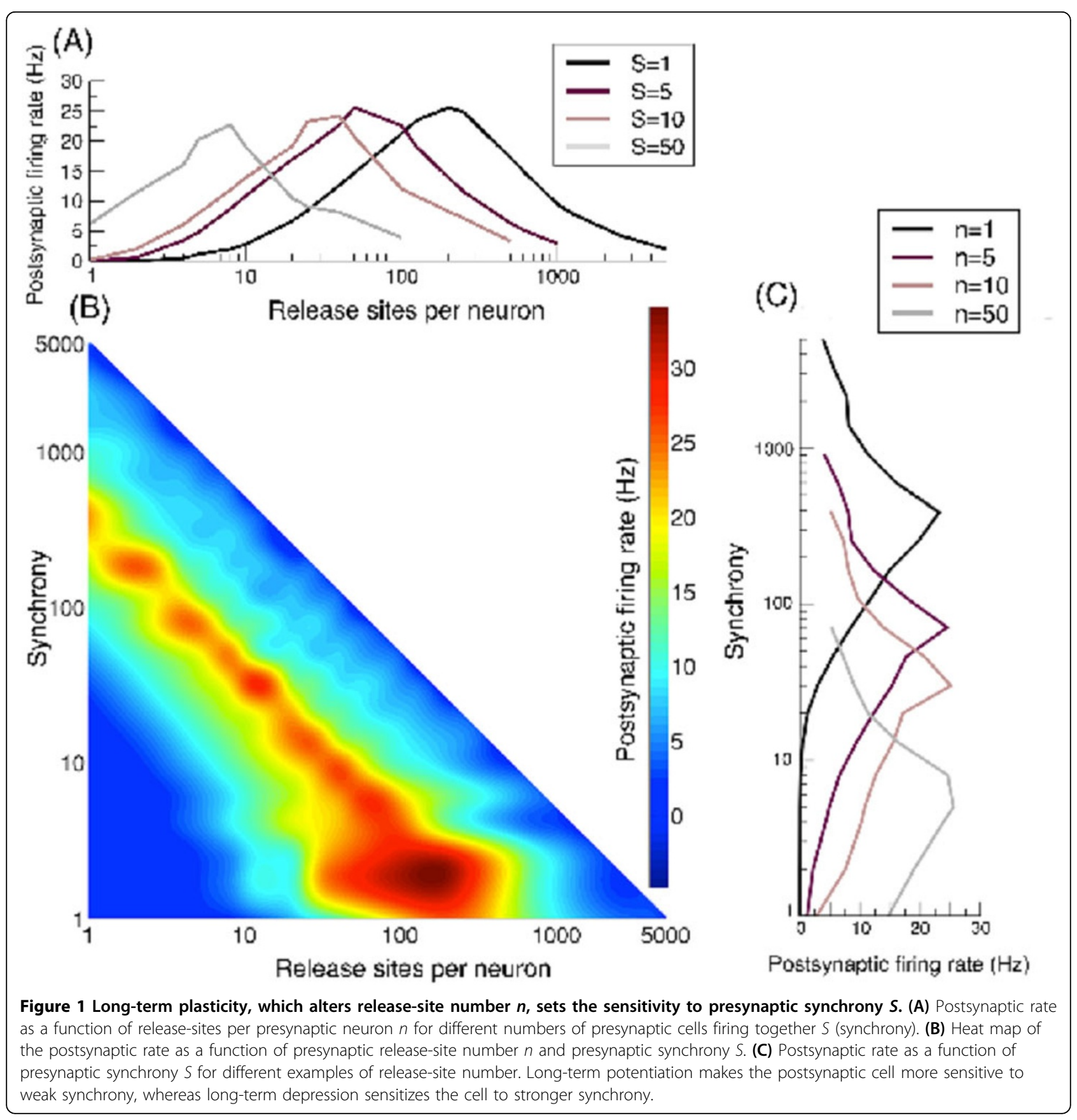

